of considerably more than a thousand wells, the greater number of which are in operation and irrigate an area of a million and a half acres. The capital outlay on the system has been about Rs. 126 lakhs $(£ 945,000)$. The execution of the "Grid" project has been in the hands of Sir William Stampe, formerly chief engineer of the Irrigation Department of the United Provinces.

\section{Tring Museum}

About the time of the recent meeting of the British Association in Nottingham, it was announced in the Press that the late Lord Rothschild had bequeathed the buildings and collections of his museum at Tring to the nation on condition that the trustees of the British Museum should undertake their custody and maintenance. The president of the Association, Sir Edward Poulton, expressed in his address the hope that this condition would be accepted, and the committee of Section D (Zoology) forwarded a resolution to the Council, recording its opinion "that the continuance of the Tring Museum as an active centre of scientific research is a matter of the utmost importance from a national, and indeed from an international, point of view. For many years", the resolution continues, "the collections preserved there, more particularly the vast and unequalled collection of Lepidoptera, have attracted research workers from all over the world and have been the means of adding largely to our understanding of the problems of geographical variation. The Sectional Committee earnestly desire that the permanent conservation of these collections and the continuance of the facilities for their study provided by the munificence of the late Lord Rothschild will be ensured by their being placed in the custody of the Trustees of the British Museum." The Council of the Association has now adopted this resolution.

\section{Royal Institute of International Affairs}

THE report of the Council of the Royal Institute of International Affairs submitted to the eighteenth annual general meeting on November 2 refers to the establishment of a chair of international economics at the Institute, Chatham House, London, S.W.1, as a result of a gift of $£ 20,000$ from Sir Henry Price. Prof. Allan G. B. Fisher, of the University of Western Australia, has been appointed as the first holder of this chair and will assume his duties in January 1938. It is hoped that this is the first of what will become a group of research chairs devoted to the study of international affairs, and the council contemplates the establishment of research chairs in British Commonwealth relations, international law and institutions and Far Eastern affairs as soon as provision can be made for them. In addition to these important developments, which were largely inspired by the work of Prof. Arnold Toynbee, holder of the Stevenson research chair in international history, the council has been able to maintain its programme of research by individual scholars and by study groups through the support of the trustees of the Rockefeller
Foundation, who in January 1937 renewed for a further five years their grant of $£ 8,000$ a year. Four reports in the Study Group Series were completed during the year, covering "The British Empire", "The Problem of International Investment", "The Colonial Problem" and "The Republics of South America : a Political, Economic and Cultural Survey". Particulars of these, and of other publications of the Institute, are included in an appendix. The Rockefeller Foundation has also made a special grant for an investigation of the refugee problem. The report includes particulars of a number of other research projects which are in progress as well as meetings held and study groups in being. It is expected that the African Research Survey will be completed and published early in 1938, the preliminary survey having been extended to cover administration, economics, scientific research and social relations.

\section{Tyneside Geographical Society}

THE Tyneside Geographical Society celebrated its fiftieth year of existence at Newcastle-upon-Tyne on November 4-6. On November 4 a jubilee meeting was held with the president of the Society, the Duke of Northumberland, in the chair. The chief speaker at this meeting was Sir William Goodenough, who was one of the two representatives of the Royal Geographical Society at the celebrations. After this meeting, a dinner was held at the Royal Station Hotel, when Lord Polwarth, president of the Royal Scottish Geographical Society, proposed the health of the Tyneside Geographical Society. Sir Thomas Oliver acknowledged the toast and included in his response references to the past activities of the Society over the last fifty years. The health of the guests was proposed by Mr. Herbert Shaw, who held the office of secretary of the Society for nearly forty years. He expressed the gratitude of the Society to the Royal Geographical Society, the Royal Scottish Geographical Society, the Geographical Association and the Manchester Geographical Society for sending representatives to the celebrations. The toast was acknowledged by Lord Eustace Percy, rector of King's College, and by Prof. E. G. R. Taylor of Birkbeck College, University of London. On November 5 the Herbertson Memorial Lecture of the Geographical Association was delivered in King's College by Prof. A. G. Ogilvie, of the University of Edinburgh. The subject of the lecture was "Minerals, Land Forms and Life". On November 6 an exhibition of geographical materials, publications and appliances was held, the official opening ceremony being performed by Lord Eustace Percy.

\section{County Library at Ruislip}

That a timbered barn, reputed to be of medieval age, used in olden days for the storage of corn and later for haybinders' work and general farm products, might be saved by its own appeal through adaptation for the needs of a public county library is a con. sideration which might well enter the minds of educational authorities in those rapidly expanding rural areas where sites are valued at exorbitant rates 